\title{
Effect of Wnt/B-catenin and NF-kB Signaling Pathways on Mucus Secretion with Hypertonicity in 16HBE Cells
}

\author{
Liu Xiaoyan ${ }^{1}$ and Zhou Xiangdong ${ }^{2 *}$ \\ ${ }^{1}$ Department of Geriatrics, the First Affiliated Hospital; Chongqing Medical University; No.1 Youyi Road; Yuzhong \\ District, Chongqing; 400016 - China. ${ }^{2}$ Department of Respiratory Medicine, the Second Affiliated Hospital; \\ Chongqing Medical University; No.74, Linjiang Road; Yuzhong District, Chongqing; 400010 - China
}

\begin{abstract}
This study aimed at identifying the molecular mechanisms and effects of hypertonicity on mucin5AC (MUC5AC) expression in airway epithelial cells for which immortalized human bronchial epithelial (16HBE) cells were cultured in $600 \mathrm{mOsm} / \mathrm{L}$ hypertonic medium for different times in vitro. Proteins of MUC5AC and $\beta$-catenin, Cyclin $D 1, N F-\kappa B$ p65 were detected by enzyme linked immunosorbent assay (ELISA), reverse transcription (RT)-PCR and western blotting assays. After transfection of $\beta$-catenin siRNA in 16HBE cells, the levels of $\beta$-catenin, Cyclin D1, $N F-\kappa B$ p65 and MUC5AC protein were detected. Results showed that the levels of mRNAs and proteins of target genes increased significantly after the exposure to hypertonic conditions and the expression content increased in a time-dependent manner. Furthermore, transfection with $\beta$-catenin siRNA attenuated the expression of these genes. These results suggested that the Wnt/ $\beta$-catenin and $N F-\kappa B$ signaling pathways played essential roles in inducing the $M U C 5 A C$ hypersecretion in $16 H B E$ cells in response to hypertonicity.
\end{abstract}

Key words: MUC5AC, hypertonicity, Wnt/ $\beta$-catenin, NF- $\kappa$ B p65

\section{INTRODUCTION}

Mucus hypersecretion is a characteristic manifestation in the patients with chronic obstructive pulmonary diseases (COPD) (Fahy 2001; Hogg et al. 2004). Mucus hypersecretion contributes to morbidity and mortality in these diseases by plugging the airways and causing recurrent infections (Shao and Nadel 2005). MUC5AC is the main mucin phenotype expressed in airway epithelium, especially in the pathological state. The physical or chemical changes of the airway affect the secretion of the mucus. For instance, high osmotic pressure of airway can serve as a kind of physical stimulation, which induces the human bronchial epithelial cells to secrete mucus. Some $3-5 \%$ of the high permeability brine is often used to discharge sputum clinically. Studies have shown that high osmotic pressure of airway caused mucus hypersecretion and its probable molecular mechanisms could be the expression of HSP70-2, which was activated by $\mathrm{PKC} \mu$ signaling pathway. The OREBP (osmotic response element binding protein) links the pathway and molecular of HSP70-2. It combines with the ORE2 sites, the upstream promoter of HSP70-2, and then activates the transcription of HSP70-2. Such mechanisms promote the hypersecretion of MUC5AC. Nevertheless, the inhibitor of $\mathrm{PKC} \mu$ can not suppress the secretion of MUC5AC completely, which implies that other signaling pathways may involve together in the process of hypersecretion of the MUC5AC in the high permeability

*Author for correspondence: arrivetosuccess@ sohu.com 
environment of airway. Wnt/ $\beta$-catenin signaling pathway is the focus of studies in variant provinces nowadays. Previous studies have shown that the disorders of this pathway get relationships with bronchial asthma, pulmonary fibrosis and lung cancer (Voynow and Rubin 2009; Kneidinger et al. 2011; Baarsma et al. 2011). NF- $\mathrm{kB}$ signaling pathway is another important pathway. However, little attention has been focused on the effect of Wnt/ $\beta$-catenin and NF- $\mathrm{kB}$ signaling pathways on mucus secretion with hypertonicity in airway epithelial cells both domestic and overseas. This work aimed to study the MUC5AC secretion of 16HBE cells in hypertonic conditions and discuss its possible mechanisms.

\section{MATERIALS AND METHODS}

\section{Materials}

Fetal bovine serum (FBS), trypsin, the Roswell Park Memorial Institute (RPMI) 1640 medium, TRIzol and anti- $\beta$-actin monoclonal antibody were obtained from Sigma (St. Louis, MO). The mouse monoclonal antibody to MUC5AC was obtained from Neomarker (Fremont, CA). Goat serum albumin, Mouse monoclonal antibodies to $\beta$ catenin, NF-kB p65, and Cyclin D1 and diaminobenzidine (DAB) were purchased from Santa Cruz Biotechnology (Santa Cruz, Calif). The ELISA Kit for MUC5AC, $\beta$-catenin siRNA and the control siRNA were purchased from R\&D (USA). Mouse anti-rabbit glyceraldehydes-3phosphate dehydrogenase (GAPDH) antibody and western blot stripping reagent were obtained from Chemicon International (Temecula, CA). $\beta$ catenin, NF- $\kappa \mathrm{B}$ p65 and Cyclin D1 primers, PCR reagent kit and cDNA reagent kit were generously provided by the Medical Department, Gene Research Center, University of Hong Kong. Electrochemiluminescence (ECL) reagent kit was purchased from Keygen (Nanjing, China). Moloney murine leukemia virus (MMLV) reverse transcriptase kit was supplied by Shanghai Sangon Biological Engineering Technology \& Services Corporation.

\section{Cell Culture}

The $16 \mathrm{HBE}$ cells were obtained from CloneticsBioWhittaker (San Diego, CA). A 10\% sodium chloride solution was added into RPMI 1640 medium to make $600 \mathrm{mOsm} / \mathrm{L}$ hypertonic culture system. Theses cells were plated in a six-well plate with $5-6 \times 10^{5}$ cells per well and cultured in $2 \mathrm{ml}$ RPMI 1640 medium with $10 \%$ FBS, penicillin $(100 \mathrm{U} / \mathrm{ml})$, streptomycin $(100 \mu \mathrm{g} / \mathrm{ml})$ at $37^{\circ} \mathrm{C}$ in a humidified $5 \% \quad \mathrm{CO}_{2}$ atmosphere. At $90 \%$ confluence, the cells were serum-starved in the presence or absence of additional growth factors for $24 \mathrm{~h}$. The osmotic pressure was tested by the advanced wescor and each test was repeated three times.

\section{Elisa}

The MUC5AC protein expression was measured by the ELISA. The HBE16 cells were divided into normal control group, 6h hypertonic group, $12 \mathrm{~h}$ hypertonic group, 24h hypertonic group and $48 \mathrm{~h}$ hypertonic group. Briefly, culture supernatants and cell lysates were prepared with phosphate-buffered saline (PBS) at multiple dilutions and 50 $\mu$ lof each sample was incubated with an equal volume of bicarbonate-carbonate buffer at $40^{\circ} \mathrm{C}$ in a 96 -well plate until dry. Plates were washed three times with PBS and blocked with $2 \%$ FBS for 1 h at room temperature. Plates were again washed three times with the PBS and then incubated with $50 \mu 1$ of mouse monoclonal MUC5AC antibody (1:100), which was diluted with the PBS containing $0.05 \%$ Tween-20, and dispensed into each well. After 1h, the wells were washed three times with PBS and $100 \mu \mathrm{l}$ of horseradish peroxidase-conjugated goat anti-mouse immunoglobulin G (1:10000) was dispensed into each well. After $1 \mathrm{~h}$, plates were washed three times with the PBS. Color reaction was developed with 3, 3, 5, 5-tetramethylbenzidine (TMB) peroxidase solution and stopped with $1 \mathrm{~mol} / 1 \mathrm{H}_{2} \mathrm{SO}_{4}$. The absorbance was read at $450 \mathrm{~nm}$ (Sunrise remote; Tecan) and the results were calculated by comparison with a set of standards.

\section{Western Blot Analysis}

The expressions of $\beta$-catenin, Cyclin D1 and NF$\kappa \mathrm{B}$ p65 proteins were measured by western blotting. The HBE16 cells were divided into normal control group, $12 \mathrm{~h}$ hypertonic group, $24 \mathrm{~h}$ hypertonic group and $48 \mathrm{~h}$ hypertonic group. Briefly, the cells were harvested and washed three times with the PBS. The cell pellets were resuspended in lysate buffer (radioimmunoprecipitation assay buffer, 150 $\mathrm{mmol} / \mathrm{l}$ sodium chloride, $50 \mathrm{mmol} / \mathrm{l}$ Tris- $\mathrm{HCl}$ [pH7.5], $1 \%$ tritonX-100, $1 \%$ sodium deoxycholate, $0.1 \%$ sodium dodecyl sulfate [SDS], and $2 \mathrm{mmol} / \mathrm{l}$ EDTA), lysed on ice for $20 \mathrm{~min}$, and then centrifuged at $12000 \mathrm{rpm}$ for $15 \mathrm{~min}$ at $4^{\circ} \mathrm{C}$ to 
remove the nuclei and unbroken cells. Aliquots of supernatants containing the equal amounts of protein were suspended in SDS sample buffer and boiled for $5 \mathrm{~min}$. Proteins were separated by SDS polyacrylamide gel electrophoresis. The resulting gels were equilibrated in transfer buffer (25 $\mathrm{mmol} / \mathrm{l}$ Tris- $\mathrm{HCl}, 192 \mathrm{mmol} / \mathrm{l}$ glycine, and 20\% methanol [pH8.3]), and the proteins were transferred electrophoretically to polyvinylidene difluoride membranes (Bio-Rad), and incubated for $1 \mathrm{~h}$ with PBS containing 5\% skimmed milk and $0.05 \%$ Tween 20 . At this point, the membranes were incubated with anti-bodies to $\beta$-catenin, Cyclin D1 and NF- $\kappa$ B p65 (all at 1:1000) for $2 \mathrm{~h}$ at room temperature. Specific biotinylated goat antimouse antibodies (all at 1:1000) were used to detect the primary antibodies, followed by incubation with horseradish peroxidase-conjugated avidin complex (1:10000). Blots were developed with the ECL kit according to the manufacturer's instruction. The intensity of bands identified by the specific antibodies was expressed as the ratio to band intensity for $\beta$-actin.

\section{RT-PCR}

The HBE16 cells were divided into normal control group and $24 \mathrm{~h}$ hypertonic group. By using the Trizol, total RNA were extracted from the $16 \mathrm{HBE}$ cells of both the groups and qualities were verified by resolving the samples using $1 \%$ agarose gel electrophoresis. A260/280 was within the range of 1.8-2.0. The cDNA was generated from RNA using Oligo (dT) primer and reverse transcribed with the MMLV reverse transcriptase kit. Primers: $\beta$-catenin, forward-5'GCTGATTTGATGGAGTTGGACATGG -3', reverse-5' - GCCAAACGCTGGACATTA GTGG -3'. Cyclin D1, forward-5' ATGCCAACCTCCTCAACGACC -3', reverse5' - TGG CACAGAGGGCAACGAAGG -3'. NF$\kappa \mathrm{B}$ p65, forward-5'- CGCGGATCCTGGCTCGT CTGTAGTGCACG -3', reverse-5' CCCAAGCTTTAGAAGCCATCCCGGCAGTC 3'. GAPDH, forward-5' AGTGGATATTGTTGCCATCA -3', reverse-5' GAAGATGGTGAT GGGATTTC -3 '. PCR conditions: denatured at $94^{\circ} \mathrm{C}$ for $10 \mathrm{~min}, 94^{\circ} \mathrm{C}$ for $30 \mathrm{~s}, 57^{\circ} \mathrm{C}$ for $45 \mathrm{~s}, 70^{\circ} \mathrm{C}$ for $45 \mathrm{~s}$, for 30 cycles, $72^{\circ} \mathrm{C}$ for $7 \mathrm{~min}$. PCR products were resolved by using 2\% agarose gel electrophoresis and bands visualized by ethidium bromide staining.
Small Interfering RNA Preparation and Transfect of $\beta$-catenin siRNA

One day before the transfection, the cells were plated in growth medium without antibiotics per well. Therefore, they were $90-95 \%$ confluent at the time of transfection. Next, the cells were transfected with siRNA (either the control, or $\beta$ catenin) using Lipofectamine 2000 and Opti-MEM reduced serum medium according to the manufacturer's recommendations. All the studies were performed when 16HBE cells were 90-95\% confluent. After the cells reached the confluence, they were serum-starved for $24 \mathrm{~h}$ and divided into the following groups: (1) the $600 \mathrm{mOsm} / \mathrm{L}$ hypertonic (HT) group: cells were treated with $600 \mathrm{mOsm} / \mathrm{L}$ hypertonic RPMI 1640 medium, (2) the HT +the control siRNA group: cells were transfected with negative-control siRNA, and then treated with $600 \mathrm{mOsm} / \mathrm{L}$ hypertonic RPMI 1640 medium for $24 \mathrm{~h}$, (3) the HT $+\beta$-catenin siRNA group: cells were transfected with $\beta$-catenin siRNA and incubated with $600 \mathrm{mOsm} / \mathrm{L}$ hypertonic RPMI 1640 medium for $24 \mathrm{~h}$, (4) the isotonic group: cells were grown in normal RPMI 1640 medium $(300 \mathrm{mOsm} / \mathrm{L})$. The changes of expressions of $\beta$-catenin, Cyclin D1, NF- $\kappa \mathrm{B}$ p65 and MUC5AC proteins in these groups were monitored by the western blotting.

\section{Statistical Analysis}

All of the data are presented as mean (SD) $(n=3)$. Data were analyzed by using the SPSS17.0 statistical package. The analysis of variance was used to determine statistically significant differences. If the probability was less than 0.05 , namely $\mathrm{P}<0.05$, the null hypothesis was considered to be significant.

\section{RESULTS}

Influence of different times of hypertonic culture on MUC5AC secretion of 16HBE

Studies on the effects of hypertonicity on the expression of MUC5AC in the 16HBE cells, as monitored by the ELISA showed that the treatment with different times $(0,6,12,24,48 \mathrm{~h})$ of $600 \mathrm{mOsm} / \mathrm{L}$ hypertonic medium significantly improved the secretion of MUC5AC (all $P<0.05$ ). These data indicated a time-dependent relationship of MUC5AC by hypertonicity in the 16HBE cells (Fig.1). 


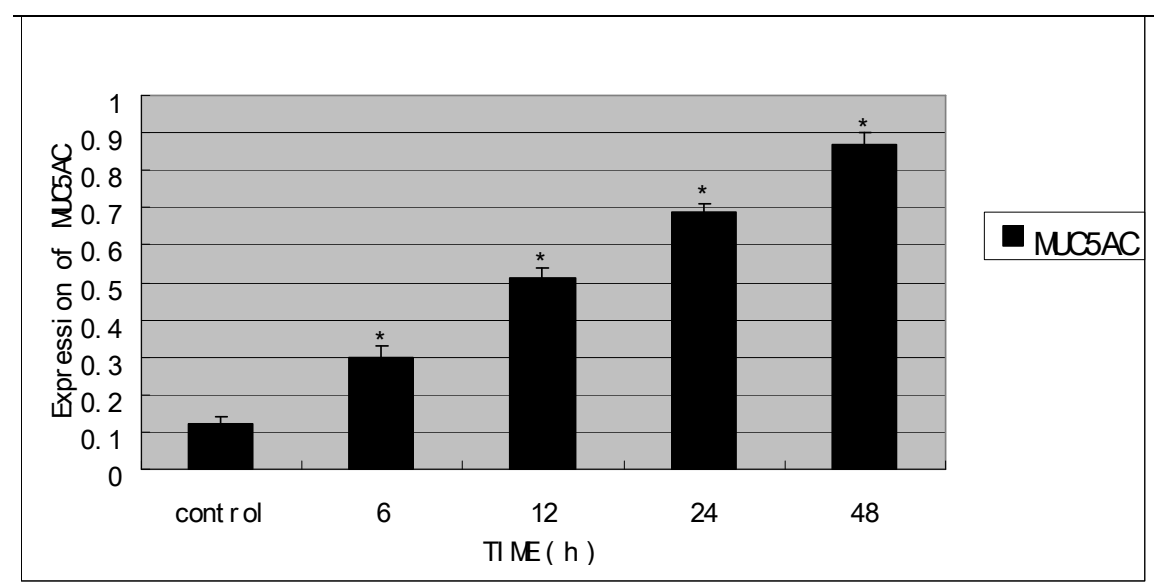

Figure 1 - Expression of MUC5AC protein in each group by ELISA $* P<0.05$ versus control group.

Wnt/ $\beta$-catenin signaling pathway modulates expression of MUC5AC induced by hypertonicity in $16 \mathrm{HBE}$ cells

Results for the effects of manipulating Wnt/Bcatenin signaling pathway on the MUC5AC expression stimulated by hypertonicity were statistically significant. The $16 \mathrm{HBE}$ cells were cultured in $600 \mathrm{mOsm} / \mathrm{L}$ hypertonic conditions for different times $(0,12,24,48 \mathrm{~h})$. The expression levels of $\beta$-catenin and Cyclin D1 proteins were evaluated by the western blot analysis. The treatment with $600 \mathrm{mOsm} / \mathrm{L}$ hypertonic medium significantly boosted the expression of $\beta$-catenin and Cyclin D1 proteins (all $P<0.05$ ) (Fig.2). Similar results were obtained when the expression levels of $\beta$-catenin and Cyclin D1 mRNA were increased markedly by RT-PCR assay $(P<0.05)$ (Fig.3). The knockdown of endogenous $\beta$-catenin for $24 \mathrm{~h}$ by si- $\beta$-catenin resulted in about 2 -fold reduction in the expression levels of the MUC5AC, $\beta$-catenin and Cyclin D1 proteins compared to the hypertonicity group (all $P<0.05$ ) (Fig.4). These results suggested that Wnt/ $\beta$-catenin signaling pathway might play a vital role in the upregulation of MUC5AC in hypertonic conditions.

\section{Oh $12 \mathrm{~h} \quad 24 \mathrm{~h} \quad 48 \mathrm{~h}$}
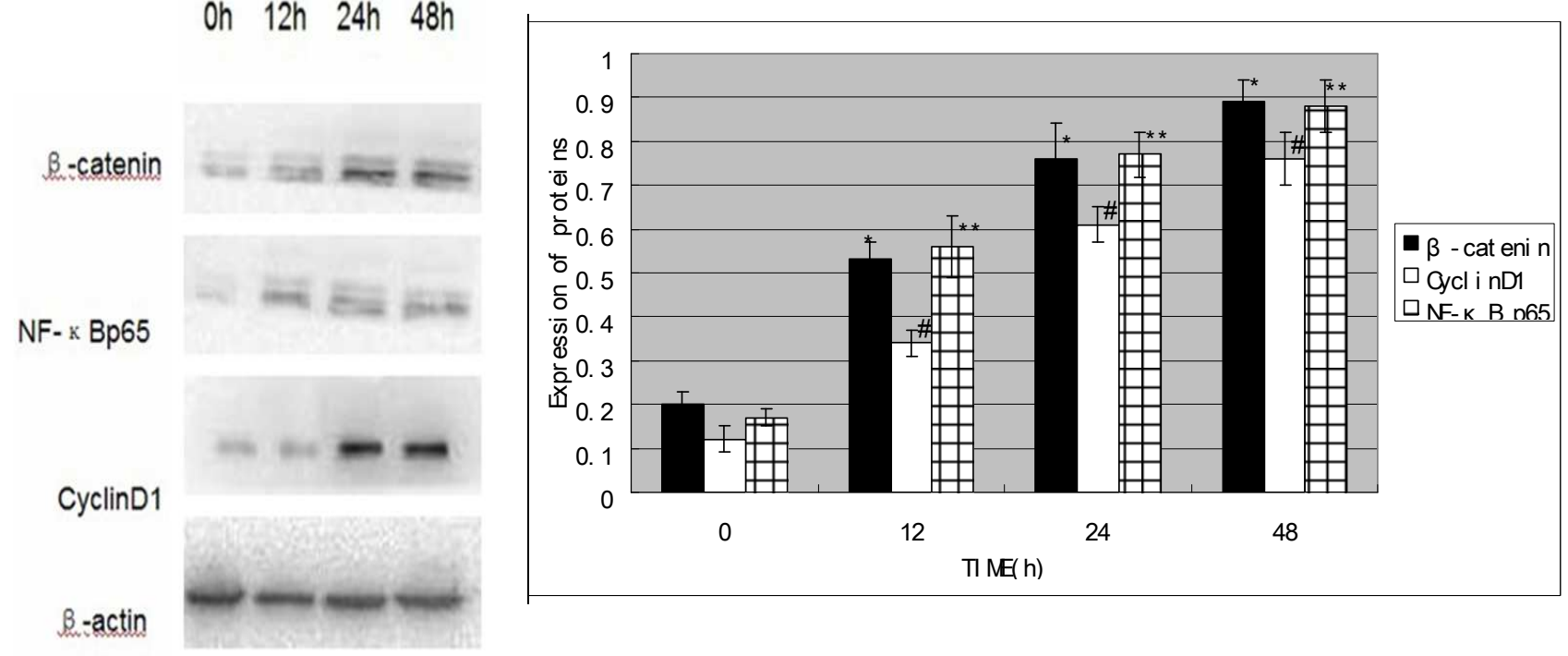

Figure 2 - Expression of $\beta$-catenin, Cyclin D1 and $N F-\kappa B$ p65 in groups which were trained in hypertonic atmosphere for different times by western blotting. $* P<0.05$ experimental groups versus control group of expression of $\beta$-catenin, $\# P<0.05$ experimental groups versus control group of expression of Cyclin D1, $* * P<0.05$ experimental groups versus control group of expression of NF- $\kappa \mathrm{B}$ p65. 


\section{ctrl $24 \mathrm{~h}$}

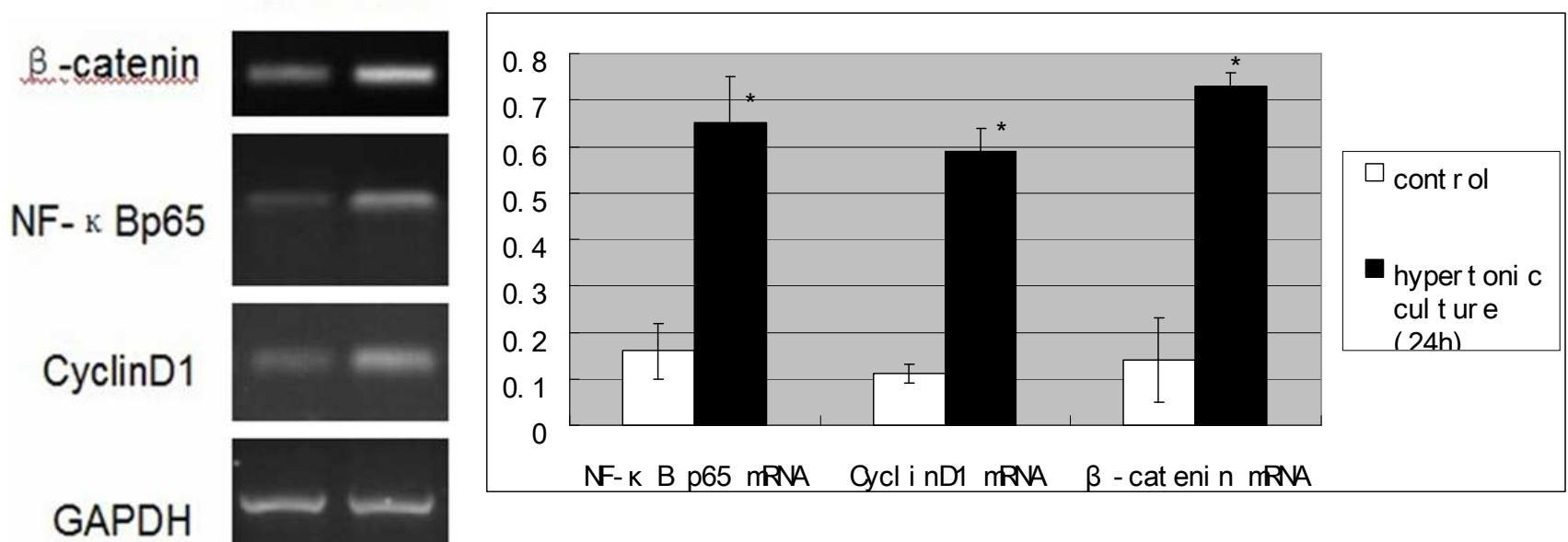

Figure 3 - Expression of $\beta$-catenin, Cyclin D1 and NF-kB p65 mRNAs in groups which were trained in hypertonic atmosphere for different times by RT-PCR. $* P<0.05$ experimental groups versus control group.

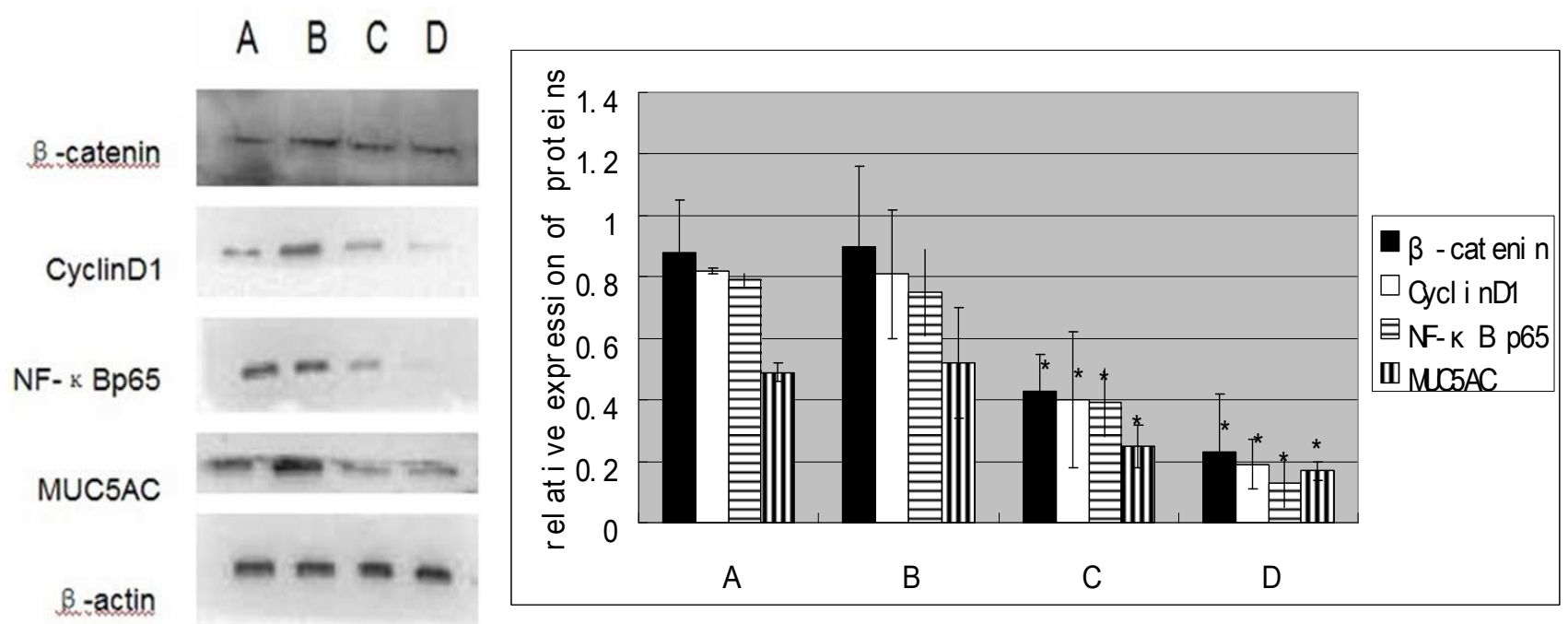

Figure 4 - The cells were divided into four different treatment groups. The cells were transfected with $10 \mathrm{nmol} / \mathrm{L} \beta$-catenin siRNA or control siRNA. Group A signifies hypertonicity group. Group B signifies hypertonicity with $10 \mathrm{nmol} / \mathrm{L}$ control siRNA for $24 \mathrm{~h}$. Group $\mathrm{C}$ signifies hypertonicity with $10 \mathrm{nmol} / \mathrm{L} \beta$-catenin siRNA for $24 \mathrm{~h}$. Group D signifies isotonicity group. The cell lysates were analysed by western blotting with $\beta$-catenin, Cyclin D1, NF- $\kappa \mathrm{B}$ p65 and MUC5AC antibodies. $* \mathrm{p}<0.05$, compared with hypertonicity group (Group A). Data are shown as mean \pm S.D. of three independent experiments.

NF-KB signaling pathways modulates expression of MUC5AC induced by hypertonicity in $16 \mathrm{HBE}$ cells

To further confirm the mechanisms in the regulation of MUC5AC by hypertonicity, the NF- $\kappa \mathrm{B}$ signaling pathways was testred. The results were statistically significant. The $16 \mathrm{HBE}$ cells were cultured in $600 \mathrm{mOsm} / \mathrm{L}$ hypertonic conditions for different times $(0,12,24,48 \mathrm{~h})$. The levels of NF-kB p65 protein expression were 
evaluated by the western blotting. The treatment with $600 \mathrm{mOsm} / \mathrm{L}$ hypertonic medium significantly boosted the expression of NF-kB p65 protein (all $P<0.05$ ) (Fig.2). Similar results were obtained when the level of NF- $\mathrm{kB}$ p65 mRNA expression was increased markedly by RT-PCR assay $\quad(P<0.05) \quad$ (Fig.3). Knockdown of endogenous $\beta$-catenin by si- $\beta$-catenin for $24 \mathrm{~h}$ resulted in about 2-fold reduction in the expression level of NF-kB p65 protein compared to the hypertonicity group (all $P<0.05$ ) (Fig.4). These results suggested that NF- $\kappa B$ signaling pathway might play a positive role in the upregulation of MUC5AC in hypertonic conditions.

\section{DISCUSSION}

Excessive mucus secretion is one of the most indispensable pathological traits of a variety of chronic airway inflammatory diseases. The expression of MUC5AC is regulated by the multiple signaling pathways, such as ERK, JNK, $\mathrm{p} 38$, and signal transducer and activator of transcription pathways ( $\mathrm{Yu}$ et al. 2011; Lim et al. 2009). Clinically, 3-5\% hypertonic sodium chloride solution is often used to induce and get rid of airway mucus. However, little information has been focused on its mechanisms. This study showed that hypertonicity exerted a timedependent upregulation of the MUC5AC in $16 \mathrm{HBE}$ cells. Augmented expression of $\beta$-catenin, Cyclin D1 and NF- $\kappa$ B p65 stimulated the expression of MUC5AC, while, conversely, the knockdown of $\beta$-catenin resulted in a notable decrease in Cyclin D1, NF- $\kappa$ B p65 and MUC5AC. These findings indicated that $\beta$-catenin played a positive role in the regulation of MUC5AC production. Furthermore, both $\mathrm{Wnt} / \beta$-catenin and $\mathrm{NF}-\kappa \mathrm{B}$ pathways were involved in the action of $\beta$ catenin. These results collectively highlighted a crucial role for $\beta$-catenin in the control of mucus secretion of $16 \mathrm{HBE}$ cells in vitro, and $\mathrm{Wnt} / \beta$ catenin and NF- $\mathrm{KB}$ signaling pathways could be one of the important causes for the excessive secretion of MUC5AC in hypertonic atmosphere.

Wnt signaling pathway is divided into three types: the $\mathrm{Wnt} / \beta$-catenin signaling pathway, $\mathrm{Wnt} / \mathrm{Ca}^{2+}$ signaling pathway and the Wnt/PCP signaling pathway. Wnt/ $\beta$-catenin signaling pathway is the most classic one, which is also known as the canonical Wnt signaling pathway, which regulates the differentiation, migration, proliferation and polarity of the cells (Yao et al. 2011). It also involves in regulating the expressions of many genes. It is reported that the abnormal activation of this pathway takes positive effect in the formation of a variety of tumors (Amado et al. 2011; Bulut et al. 2011; Sethi et al. 2011). The anomalous activation of $\beta$-catenin in the nucleus is regarded as a sign of abnormal activation of Wnt signaling pathway. The abnormal activation of Wnt ligand leads to proliferation of epithelial cells and fibrosis of lung. Wang et al. (2011) reported that COPD patients with Wnt signaling pathway inhibited had a reduction in the ability to repair the damages and injuries of the lung. Morrisey (2003) showed that $\mathrm{Wnt} / \beta$-catenin signaling pathway played a critical role in the repair process in lung tissue. Huang et al. (2008) found that cigarette somking could upregulate the $\mathrm{Wnt} / \beta$-catenin signaling pathway. This signaling pathway is also known to have relationships with mucus production and secretion (Konigshoff and Eickelberg 2010). However, previous studies have failed to explain the role of the $\mathrm{Wnt} / \beta$-catenin signaling pathway in mucus hypersecretion of hypertonic conditions.

$\beta$-catenin is the core molecule of $\mathrm{Wnt} / \beta$-catenin signaling pathway, which has been found as an adhesion molecule originally. It is a multifunctional protein, is produced by the CTNNB1 gene ( $88 \mathrm{kD}$ size) and located in 3p22p21.3 of human chromosome (Morin and Weeraratna 2003). $\beta$-catenin is composed of 781 amino acids and contains 12 Armadillo (arm) regions and special structures of $\mathrm{N}$-terminal and $\mathrm{C}$ terminal. With plenty of Ser/Thr residues, Nterminal of $\beta$-catenin is comprised of 130 amino acids and controls the stability of $\beta$-catenin. Cterminal of $\beta$-catenin is comprised of 100 amino acids, which regulates the transcription of target genes downstream (Willert and Nusse1998). In normal conditions, $\beta$-catenin is mainly localized in the cell membrane, with the functions of mediating cell adhesion and regulating expression of the genes. Mucenski et al. (2005) pointed out that the long-term activation of $\beta$-catenin could lead to the hyperplasia of airway goblet cells. Since it is wellknown that airway mucus is secreted by the goblet cells, $\beta$-catenin is expected to be closely related to the mucus hypersecretion of airway. Farkas et al. (2005) reported that thehypertonic liquid could induce reversible phosphorylation of $\beta$-catenin in the epithelial cells of the brain. It suggested that there could be some connections with $\mathrm{Wnt} / \beta$ catenin signaling pathway and high osmotic 
pressure. The present findings showed that $\beta$ catenin was increased when $16 \mathrm{HBE}$ cells were cultured in the hypertonic atmosphere, which demonstrated that Wnt/B-catenin pathway was activated.

Encoding 295 amino acids, Cyclin D1 gene, the key element of $\mathrm{Wnt} / \beta$-catenin signaling pathway, is located on 11q1-3 of chromosome. Cyclin D1 gene is one of the target genes of $\beta$-catenin/LEF-1 complex (Shtutman et al. 1999). Cyclin D1 gene was originally found in the parathyroid. It can induce the growth of tumors in parathyroid in transgenic mice and adjust the transmission of $\mathrm{Ca}^{2+}$. It is also the regulator for macrophage transfer (Imanishi et al. 2001; Neumeister et al. 2003). The overexpression of Cyclin D1 can shorten the G1 phase of the cell cycle and prompt the cells into $\mathrm{S}$ phase, which causes the uncontrolled growth and arrests differentiation of cells. Hence, the variation of Cyclin D1 is closely related with the occurrence of a variety of tumors. However, no studies have focused on the relationships between the airway mucus hypersecretion in hypertonic conditions and Cyclin D1 gene yet. The present results showed that Cyclin D1, as a downstream gene of Wnt/ $\beta$ catenin pathway, was also increased significantly, which demonstrated that $\mathrm{Wnt} / \beta$-catenin pathway was activated further.

There are binding sites for NF- $\mathrm{KB}$ gene in the promoter of MUC5AC, which indicates that NF$\kappa \mathrm{B}$ plays a key role in the formation and secretion of mucus. Although working independently, NF$\kappa \mathrm{B}$ and $\mathrm{Wnt} / \beta$-catenin signaling pathways have close relationships. A series of studies have found that there is a "crosstalk" between the two signaling pathways, which is mediated by the $\beta$ TrCP. I $\mathrm{I} B$ and $\beta$-catenin have an identical structure-DAGX2 $+\mathrm{nS}$ degradation domains. Phosphorylated Ser32, Ser36 of IKB and phosphorylated Ser33, Ser37 of $\beta$-catenin can bind with the WD40 of $\beta-\operatorname{TrCP}$, and then be degraded. Hence, the content of NF- $\mathrm{KB}$ p 65 protein increased when $16 \mathrm{HBE}$ cells were cultured in the hypertonic atmosphere and such change was the same as $\mathrm{Wnt} / \beta$-catenin pathway.

\section{CONCLUSIONS}

From the results it could be concluded that the proteins of $\beta$-catenin, Cyclin D1 and NF- $\mathrm{B}$ p65 played a positive role in the hypertonicity stimulated MUC5AC production of 16HBE cells. The results demonstrated that both $\mathrm{Wnt} / \beta$-catenin and NF- $\kappa \mathrm{B}$ signaling pathways were involved in this process. Further studies are ought to focus on the role of $\mathrm{Wnt} / \beta$-catenin and $\mathrm{NF}-\mathrm{KB}$ signaling pathways in the airway mucus secretion in vivo. These findings in vitro encourage the explorations of the therapeutic potentials of manipulating $\beta$ catenin in the management of mucus overproduction in chronic inflammatory airway diseases.

\section{REFERENCES}

Fahy JV. Remodeling of the airway epithelium in asthma. Am J Respir Crit Care Med. 2001; 164(10 Pt2): S46-51.

Hogg JC, Chu F, Utokaparch S, Woods R, Elliott WM, Buzatu L, et al. The nature of small-airway obstruction in chronic obstructive pulmonary disease. N Engl J Med. 2004; 350(26): 2645-53.

Shao MX, Nadel JA. Neutrophil elastase induces MUC5AC mucin production in human airway epithelial cells via a cascade involving protein kinase $\mathrm{C}$, Reactive oxygen species, and TNF- $\alpha$-converting enzyme. J Immunol. 2005; 175(6): 4009-16.

Voynow JA, Rubin BK. Mucins, Mucus, and Sputum. Chest. 2009; 135(2): 505-12.

Kneidinger N, Yildirim AO, Callegari J, Takenaka S, Stein MM, Dumitrascu R, et al. Activation of the Wnt/ $\beta$-catenin pathway attenuates experimental emphysema. Am J Respir Crit Care Med. 2011; 183(6): 723-33.

Baarsma HA, Spanjer AI, Haitsma G, Engelbertink LH, Meurs H, Jonker MR, et al. Activation of $W n t / \beta$ catenin signaling in pulmonary fibroblasts by TGF- $\beta$ is increased in chronic obstructive pulmonary disease. Plos One. 2011; 6(9): e25450.

Yu HM, Li Q, Kolosov VP, Perelman JM, Zhou XD. Interleukin-13 induces mucin 5AC production involving STAT6/SPDEF in human airway epithelial cells. Cell Commun Adhes. 2010; 17: 83-92.

Lim JH, Kim HJ, Komatsu K, Ha U, Huang Y, Jono H, et al. Differential regulation of Streptococcus pneumoniae induced human MUC5AC mucin expression through distinct MAPK pathways. Am J Transl Res. 2009; 1(3): 300-11.

Yao H, Ashihara E, Maekawa T. Targeting the Wnt/ $\beta$ catenin signaling pathway in human cancers. Expert Opin Ther Targets. 2011; 15(7): 873-887.

Amado NG, Fonseca BF, Cerqueira DM, Neto VM, Abreu JG, et al. Flavonoids: potential Wnt/ $\beta$ catenin signaling modulators in cancer. Life Sci. 2011; 89(15-16): 545-54. 
Bulut G, Fallen S, Beauchamp EM, Drebing LE, Sun J, Berry DL, et al. $\beta$-catenin accelerates human papilloma virus type-16 mediated cervical carcinogenesis in transgenic mice. Plos One. 2011; 6(11): e27243.

Sethi K, Sarkar S, Das S, Rajput S, Mazumder A, Roy $\mathrm{B}$, et al. Expressions of CK-19, NF- $\kappa \mathrm{B}$, Ecadherin, $\beta$-catenin and EGFR as diagnostic and prognostic markers by immunohistochemical analysis in thyroid carcinoma. J Exp Ther Oncol. 2011; 9(3): 187-199.

Wang R, Ahmed J, Wang G, Hassan I, Strulovici-Barel $Y$, Hackett NR, et al. Down-regulation of the canonical $\mathrm{Wnt} / \beta$-catenin pathway in the airway epithelium of healthy smokers and smokers with COPD. Plos One. 2011; 6(4): e14793.

Morrisey EE. Wnt signaling and pulmonary fibrosis. Am J Pathol. 2003; 162(5): 1393-7.

Huang CL, Liu D, Ishikawa S, Nakashima T, Nakashima $\mathrm{N}$, Yokomise $\mathrm{H}$, et al. Wnt1 overexpression promotes tumor progression in nonsmall cell lung cancer. Eur J Cancer. 2008, 44(17): 2680-8.

Konigshoff M, Eickelberg O. Wnt signaling in lung disease: a failure or a regeneration signal? Am J Respir Cell Mol Biol. 2010; 42(1): 21-31.

Morin PJ, Weeraratna AT. Wnt signaling in human cancer. Cancer Treat Res. 2003; 115(2): 169-87.
Willert K, Nusse R. $\beta$-catenin: a key mediator of Wnt signaling. Curr Opin Genet Dev. 1998; 8(1): 95-102.

Mucenski ML, Nation JM, Thitoff AR, Besnard V, Xu $\mathrm{Y}$, Wert SE, et al. $\beta$-catenin regulates differentiation of respiratory epithelial cells in vivo. Am J Physiol Lung Cell Mol Physiol. 2005; 289(6): L971-9.

Farkas A, Szatmari E, Orbok A, Wilhelm L, Wejksza $\mathrm{K}$, Nagyosizi P, et al. Hyperosmotic mannitol induces Src kinase-dependent phosphorylation of $\beta$-catenin in cerebral endothelial cells. J Neurosci Res. 2005, 80(6): 855-61.

Shtutman M, Zhurinsky J, Simcha I, Albanese C, D'Amico M, Pestell R, et al. The Cyclin D1 gene is a target of the beta-catenin/LEF-1 pathway. Proc Natl Acad Sci USA. 1999; 96(4): 5522-7.

Imanishi Y, Hosokawa Y, Yoshimoto K, Schipani E, Mallya S, Papanikolaou A, et al. Primary hyperparathyroidism caused by parathyroid-targeted overexpression of Cyclin D1 in transgenic mice. $J$ Clin Invest. 2001; 107(9): 1093-102.

Neumeister P, Pixley FJ, Xiong Y, Xie H, Wu K, Ashton A, et al. Cyc1in D1 governs adhesion and motility of macrophages. Mol Biol Cell. 2003; 14(5): 2005-15.

Received: October 04, 2012; Accepted: June 07, 2013 